\title{
Effect of Transaction Costs on Marketing of Small Scale Maize Farming in Limpopo Province
}

\author{
Majory O. Meliko ${ }^{1}$ \\ ${ }^{1}$ Department of Agricultural Economics and Agribusiness, Faculty of Agricuture and Veterinary Medincine, \\ University of Buea, Buea, Cameroon \\ Correspondence: Majory O. Meliko, Department of Agricultural Economics and Agribusiness, Faculty of \\ Agricuture and Veterinary Medincine, University of Buea. B. O. Box 63, Buea, Cameroon. Tel: 237-7322-5639. \\ E-mail: melikiomo@yahoo.com
}

\author{
Received: July 15, 2013 Accepted: September 24, 2013 Online Published: May 15, 2014 \\ doi:10.5539/jas.v6n6p108 URL: http://dx.doi.org/10.5539/jas.v6n6p108
}

\begin{abstract}
The deregulated and highly competitive nature of current South African markets has created new barriers for capital-poor emerging farmers. Many of these barriers are related to the cost of transacting. A linear regression model and a Multinomial logit regression model were used to predict the hypotheses that transaction costs affect the quantity sold and that factors that affect transaction cost affects market integration respectively on farmers who produce maize. From the analysis, road access, membership in a marketing institution, land size, unit price and ownership of irrigation technology affects the quantity of maize sold. While the nature of the road (P-value, 0.043) and knowledge of price ( $\mathrm{p}$-value, 0.000 ) were the two factors affecting market integration. A possible solution for the problem is the establishment of an information and communication technology centre for price dissemination and produce aggregation.
\end{abstract}

Keywords: transaction cost, small-scale farmers, marketing, linear regression, multinomial regression, South Africa

\section{Introduction}

Maize meal is a staple food in South Africa, particularly among the poor (Traub \& Jayne, 2006). Maize constitutes approximately 70 percent of grain production and covers 60 percent of the country's cropping area (Akpalu et al., 2008). Given the importance of maize in human diets, farm incomes, and agro-industries in the Southern Africa, maize market reform has importance far beyond the food sector; it is likely to be a determinant of future economic growth and food security throughout the region (Jayne et al., 1995).

In recent years, agriculture has undergone drastic changes in South Africa. Several processes have reversed the impact of discriminatory legislation, while other initiatives have deregulated and liberalised the sector. South Africa's Agricultural Marketing Act of 1996 dismantled the existing State-managed marketing infrastructure that had linked co-operatives, agro-processors, marketing boards and marketing agents within the exclusively white "Organised Agricultural" network (Qeqe \& Cartwright, 2005; NDA, 1998).

The new Act and the ensuing deregulation of agricultural marketing were intended to promote free and open agricultural commodity markets and facilitate access to markets for new black producers. The removals of trade barriers and increased competition have opened some flexibility for farmers to choose buyers for their products and suppliers of key inputs. In legislative terms, the barriers to black entry of agricultural commodity markets have been removed and financial efficiency promoted. However, the deregulated and highly competitive nature of current markets has created new barriers for capital-poor emerging farmers (Qeqe \& Cartwright, 2005; Shiferaw et al., 2006). The barriers that resource-poor farmers had to confront to enter input and output markets includes; participation in rural land and labour markets, access to credit and other financial institutions, storage facilities, accessible roads and reliable transport networks, information and know-how on contracts and prices, technology and communications networks.

The purpose of this study is to determine the importance of transaction costs and rural institutions on small-scale maize farmers in their access to markets. 


\section{Methodology}

\subsection{Data Source}

A survey of was carried-out on 312 households involving 1674 individuals. Of the 312 households, 247 belong to an irrigation scheme with the remaining 65 cultivating on dry land. A minimum of three (3) irrigation schemes were selected randomly from the five municipal districts of Limpopo province. Selections within schemes were also of a random nature. Among the farmers, a total of 19 different crops were produce, but due to the number of farmers producing a crop, reliable statistic could only be gotten from maize which was then chosen for further investigation.

\subsection{Data Analysis}

Data were fitted into a linear regression model and unto a multinomial logit regression model to test the hypotheses that transaction costs affect the quantity sold and also that factors affecting transaction cost will affect market integration respectively.

Transaction cost is divided into information, negotiation and enforcement cost. For this study, only information cost was assessed as farmers who did not sell their product were also included in the study.

\section{Linear Regression Model}

Seven marketing information variables were fitted into a simple linear regression model with the following specification;

Maize Sold $=\mathrm{C}+$ Land size + Unit Price + Membership in a farmers' organization + Condition of the road + Knowledge of price + Contract + IRRIG

Multinomial Logit Model

A multinomial logistic regression model is generally used where the dependent variable is composed of a polytomous category having multiple choices. It is considered as a simultaneous estimation of binary logit models.

Logistic Regression is a type of predictive model that can be used when the target variable is a categorical variable. It is used to predict the relationship between the predictor and response variables. The model computes the probability of the selected response as a function of the values of the predictor variables.

The multinomial logistic regression model used in this study estimates the effect of the individual variables on the probability of choosing a market for their maize produce. All transaction cost variables used for the prediction of sale volume of maize were inserted in the model.

\section{Result and Interpretation}

Of the 19 crops investigated, maize was the only crop found to have a reasonable percentage of farmers for statistical inference. As shown in Table 1, $223(71.47 \%)$ farmers were identified producing maize on a total of $218.86 \mathrm{Ha}$.

Table 1. Production characteristics

\begin{tabular}{ll}
\hline Hectares & $218.86 \mathrm{Ha}$ \\
\hline Number of farmer & 223.00 \\
Percentage of farmer & $71.47 \%$ \\
Total production & 491060.00 Tons \\
Sales volume & 246891.25 Tons \\
Sale percentage & $50.28 \%$ \\
\hline
\end{tabular}

This high percentage may be due to the fact that maize is a staple food for the majority of South Africans. This could also be supported by the fact that only about half (50.28\%) of the maize produced are sold by $39.7 \%$ of the small-scale maize farmers.

As shown in Table 2, the small scale farmers of Limpopo province are a heterogonous group of individuals. 
Table 2. General characteristics of maize farmers

\begin{tabular}{llll}
\hline Variable Name & Variable description & Distribution (\%) & Mean \\
\hline Ethnic group & Shagaan & 15.2 & \\
& Sepedi & 45.7 & \\
& Venda & 38.6 & \\
Age of Farmers & Other & 0.4 & 60.0 \\
& $=<25$ & 2.3 & \\
& $26-35$ & 3.2 & \\
& $36-45$ & 11.8 & \\
Gender of Famers & $46-55$ & 20.9 & \\
\multirow{5}{*}{ Educational Level of Farmers } & $56-65$ & 24.5 & \\
& $>65$ & 37.3 & \\
& Male & 43 & \\
& Female & 57 & \\
& No formal education & 41.5 & \\
& Primary & 27.6 & \\
Farmers with personal cell phones & Secondary & 27.6 & \\
& Tertiary & 3.2 & \\
& Having Cell phones & 71.5 & \\
& Not having cell phones & 28.5 &
\end{tabular}

While the age of the farmers was tilted to the right, the educational level tilted to the opposite direction. From the 233 maize farmers identified, $35 \%$ of the farmers have no formal education and a total of $62.5 \%$ have less than grade 8 level of education. The farming population could then be considered old with poor level of literacy.

Considering information from the production and marketing characteristics of the maize farmers, it was found that an average $606.20 \mathrm{~kg}$ of maize at was sold at 73 cent per $\mathrm{kg}$ from a mean land size of $1.95 \mathrm{ha}$.

Table 3. Distribution of transaction cost variables among maize farmers

\begin{tabular}{|c|c|c|c|}
\hline Variable & Coding & Distribution & Mean \\
\hline \multicolumn{4}{|l|}{ Dependents variables } \\
\hline Maize (quantity of maize sold in $\mathrm{Kg}$ ) & \multicolumn{2}{|l|}{ Continuous variable } & 606.20 \\
\hline \multirow[t]{3}{*}{ Market(where does the farmer sell their crop) } & $1=$ No sale & 60.3 & \\
\hline & $2=$ Local & 17.9 & \\
\hline & $\begin{array}{l}3=\text { Regional market } \\
\text { (base) }\end{array}$ & 21.9 & \\
\hline \multicolumn{4}{|l|}{ Independent Variables } \\
\hline LAND (Land size own by farmer in $\mathrm{Ha}$ ) & \multicolumn{2}{|l|}{ Continuous variable } & 1.95 \\
\hline U_Price (Unit price of maize in $\mathrm{Kg}$ ) & \multicolumn{2}{|l|}{ Continuous variable } & 0.73 \\
\hline \multirow{2}{*}{$\begin{array}{l}\text { Membership (If farmer belongs to an institution where they } \\
\text { sell together) }\end{array}$} & $1=$ Yes & 15.2 & \\
\hline & $0=$ No (base) & 84.8 & \\
\hline \multirow[t]{2}{*}{ ROAD (Condition of market to farm road) } & $1=$ Good & 58.5 & \\
\hline & $2=$ Bad (base) & 41.5 & \\
\hline \multirow[t]{2}{*}{ P_Know (Time a farmer knows the price of maize) } & $1=<2$ days before sale & 26.3 & \\
\hline & $\begin{array}{l}2=>2 \text { days before sale } \\
\text { (base) }\end{array}$ & 73.7 & \\
\hline \multirow[t]{2}{*}{ Contract (If the farmer has a contracted buyer or not) } & $1=$ Yes & 21.9 & \\
\hline & $0=\mathrm{No}($ base $)$ & 78.1 & \\
\hline \multirow[t]{2}{*}{ IRRIG (if the farmer is using irrigation?) } & $1=$ Yes & 78.1 & \\
\hline & $0=\mathrm{No}($ base $)$ & 21.9 & \\
\hline
\end{tabular}


As indicated by the characteristics, the small-scale farming population is a varying group of individuals with diverse cultural, social and economic situations. This implies that their production and marketing constraints may also differ. From the linear regression analysis below, it was found that small-scale farmers as a whole face transaction constraints due to their land size, the unit price for their produce, the condition of the road, if they are members of an institution, the time they know the product price and if they use an irrigation system. This is as a result of the significant p-values which indicate that they affect quantity of maize sold. However, the issue of whether or not they have contracts do not determine the quantity of maize sold, as indicated by the result presented in the equation below.

Table 4. Linear regression output

\begin{tabular}{|c|c|c|c|}
\hline \multirow[t]{2}{*}{ Model Variables } & \multicolumn{2}{|c|}{ Unstandardized Coefficients } & \multirow[t]{2}{*}{ Significance } \\
\hline & B & Standard Error & \\
\hline (Constant) & -1565.015 & 593.728 & $.009^{* * *}$ \\
\hline ROAD & 414.491 & 151.113 & $.007 * * *$ \\
\hline IRRIG & 478.570 & 178.986 & $.008 * * *$ \\
\hline Contract & -38.203 & 230.631 & .869 \\
\hline LAND & 491.039 & 26.282 & $.000^{* * *}$ \\
\hline U_price & 180.436 & 64.224 & $.005^{* * *}$ \\
\hline Membership & 1054.808 & 228.269 & $.000^{* * *}$ \\
\hline P_Know & -461.685 & 195.161 & $.019 * *$ \\
\hline
\end{tabular}

Where;

$\mathrm{R}^{2}=0.692$

*** indicate $\mathrm{P}<0.001$;

** indicate $\mathrm{P}<0.01$.

For the determination for market access using a multinomial logit model, the model was found to be significant $(\mathrm{P}=0.000)$ with a chi square value of 285.268 , and $-2 \log$ likelihood of 394.533 for intercept only to a value of 109.265 for the final model. Up to $85 \%$ of the model can be accounted by variability in the predictors variables as indicated by the Nagelkerke $\mathrm{R}^{2}$. All these goodness of fit indicators show that the variables used were good predictors of the model.

Table 5. Multinomial logit regression output

\begin{tabular}{lllll}
\hline & \multicolumn{2}{c}{ No Selling of Maize } & \multicolumn{2}{c}{$\begin{array}{c}\text { Selling of Maize at } \\
\text { farm gate or local Market }\end{array}$} \\
\cline { 2 - 5 } & $\mathrm{B}$ & $\mathrm{Sig}$ & $\mathrm{B}$ & $\mathrm{Sig}$ \\
\hline Intercept & 6.836 & .000 & 3.289 & .020 \\
U_pricemaize & -13.681 &. & .007 & .977 \\
LAND & -.473 & .014 & -.071 & .521 \\
{$[\mathrm{ROAD}=1]$} & -.085 & .938 & -1.655 & .043 \\
{$[$ Contract $=1]$} & .483 & .751 & -.674 & .432 \\
{$[$ Membership=1] } & 1.645 & .313 & .835 & .405 \\
{$[$ IRRIG=1] } & -.861 & .475 & .098 & .910 \\
{$[\mathrm{P}$ Known=1] } & -7.683 & .000 & -3.526 & .000 \\
N & & & & \\
Cox and Snell & .720 & & & \\
Nagelkerke & .848 & & & \\
McFadden & .674 & & & \\
\hline
\end{tabular}


From the estimated coefficients displayed in Table 5 above, only the partial coefficients of Knowledge of price before sale and the condition of the road were found to affect farmers either on a regional market or on a local market as indicated by their P-value less than 0.5. Land size and also the duration that the farmers know the price of the product affect the decision to either sell in a regional market or not to sell at all.

As the result indicates, farmers are more likely to sell in regional markets than local markets if the roads are good. Also farmers are likely to sell more in local markets if they are aware of the price more than two days before sales.

\section{Conclusion}

Markets are very important for agricultural growth because increased agricultural productivity in the absence of market opportunities can lead to lower commodity prices and incomes of farmers. However, the costs and risks associated with marketing are too high for many small-scale farmers in low-income countries. These costs are incurred in order to reduce the risk of loss from transaction failure, and are divided into information, negotiation and enforcement cost.

The study reveal that an alarming $60.3 \%$ of maize farmers do not sell their crops. This is an indication that despite liberalization, there are factors that prevent these farmers from participating in the market. In the assessment of information cost among small-scale farmers in the Limpopo province it was found that farmers will sell more maize if they have the following conditions: larger land size, better product price, good roads, irrigation technology and are aware of the price for a longer duration.

Good roads and price information seems to be one of the major problem controlling market integration. Maize is a staple food for the majority of South Africans. This therefore implies that the price of maize is highly regulated so as to ensure that the poor do not go hungry. However price is an incentive for farmers to produce, couple with the fact that most small-scale farmers are in rural areas with poor road network, a measure for improving their integration into the market will be to provide institutional support that will facilitate the sale of their products to other distant markets with minimal cost. One of such institution will be the establishment of an information and communication technology (ICT) centre.

An ICT centre can reduce the distance farmers have to sell their crops, promote assembly of products which may encourage bulk buyers, and provide timely price and production information to these farmers.

\section{References}

Akpalu, W., Hassan, R. M., \& Ringler, C. (2008). Climate variability and maize yield in South Africa. IFPRI Discussion Paper No. 8432008.

Jayne, T. S., Hajek, M., \& Van Zyl, J. (1995). An Analysis of Alternative Maize Marketing Policies in South Africa. Food Security International Development Working Papers 54700. Michigan State University, Department of Agricultural, Food, and Resource Economics.

National Department of Agriculture (NDA). (1998). Agricultural policy in South Africa: A Discussion Document. Retrieved from Http://www.nda.agric.za/docs/policy98.htm\#fourone

Qeqe, N., \& Cartwright, A. (2005). South Africa's Agricultural Commodity Markets: Understanding the rules of the game in five commodity markets with the intention of creating opportunities for emerging farmers. Surplus People's Project, Cape Town.

Shiferaw, B., Obare, G., \& Muricho, G. (2006). Rural institution and producer organisation in imperfect markets: Experience from producer marketing groups in Semi-arid Eastern Kenya. Research Workshop on collective Action and Market Access for Smallholders, 2-5 October, Cali, Colombia.

Traub. L. N., \& Jayne, T. S. (2006). Opportunities to Improve Household Food Security through Promoting Informal Maize Marketing Channels: Experience from Eastern Cape Province, South Africa. Food Security International Development Working Papers 54568. Michigan State University, Department of Agricultural, Food, and Resource Economics.

\section{Copyrights}

Copyright for this article is retained by the author(s), with first publication rights granted to the journal.

This is an open-access article distributed under the terms and conditions of the Creative Commons Attribution license (http://creativecommons.org/licenses/by/3.0/). 